\title{
STRUGTURAL GLACIOLOGY OF AN ICE LAYER IN A FIRN FOLD, ROSS ICE SHELF, ANTARGTICA: ICE GRAIN ANALYSIS
}

\author{
By JoHn R. REID \\ (Department of Geology, University of North Dakota, Grand Forks, North Dakota, U.S.A.)
}

Abstract. A highly deformed area in the Ross Ice Shelf near the Bay of Whales was studied during the 1958-59 Antarctic summer season. A series of snow-firn folds up to $8 \mathrm{~m}$. high and with a wavelength of approximately $100 \mathrm{~m}$. occurs here. Along one of these folds, a unique ice layer formed during the $1952-53$ season through refreezing of melt water. From sites along this layer approximately 2,300 ice grains were measured using the root mean square method with the least circle diameter. The data obtained indicate the following:

(1) The mean diameter of the ice grains ranges from $4.5 \mathrm{~mm}$. in the ice from the crest of the anticline to $2.5 \mathrm{~mm}$. in the zone of maximum shear stress and/or in sections having a high air bubble content.

(2) The large diameter of the ice grains at the crest is attributed to greater solar radiation resulting from their proximity to the 1958-59 snow surface, and because they are near the surface of the exposed crevasse wall.

(3) The area of maximum shear stress, which is represented by small ice grains and the presence of secondary folds, is located almost half-way between the crest and the trough.

(4) Grains in the trough are larger than those in the shear zone because of less stress, and smaller than those at the crest because of deeper burial and the presence of a crevasse bridge which eliminates all direct radiation here.

(5) The growth of the ice grains is therefore controlled by temperature, stress and impurities.

RÉsumé. Une zone très déformée de l'Ice-Shelf de Ross près de la Bay of Whales, a été étudiée durant l'été antarctique 1958-59. On trouve dans cette région une série de plissements de neige (ou névé) ayant jusqu'à $8 \mathrm{~m}$ de haut et une longueur d'onde approximative de $100 \mathrm{~m}$. Le long de l'un de ces plissements une couche de glace unique s'est formée durant la saison 1952-53 par regel de l'eau de fusion. Environ 2300 grains de glace prélevés dans ce niveau, ont été mesurés en utilisant la méthode de la racine des moyens carrés avec un cercle de moindre diamètre. Les données obtenues sont les suivantes:

$\mathrm{I}^{\circ}$ le diamètre moyen des grains de glace varie de $4,5 \mathrm{~mm}$ dans la glace de la crête de l'anticlinal, à 2,5 mm dans la zone de cisaillement maximum et/ou dans les sections ayant une teneur en bulles d'air élevée.

$2^{\circ}$ on attribue la grandeur du diamètre des grains de glace de la crête, à un plus grand rayonnement solaire résultant de leur proximité à la surface de neige de $195^{8-59}$ et à leur voisinage de la surface du mur de la crevasse exposé.

$3^{\circ}$ la zone de cisaillement maximum caractérisée par de petits grains de glace et par la présence de plissements secondaires est située à environ mi-chemin entre la crête et le creux.

$4^{\circ}$ les grains dans le creux sont plus grands que ceux de la zone de cisaillement par suite de tension moindre, et plus petits que ceux de la crête par suite d'un enfouissement plus profond et de la présence d'un pont de crevasse qui élimine ici toute la radiation directe.

$5^{\circ}$ la croissance des grains de glace dépend donc de la température, des tensions et des impuretés.

Zusammenfassung. Während des antarktischen Sommers 1958-59 wurde ein stark zerrissenes Gebiet des Ross-Eisschelfes dicht bei der Bay of Whales untersucht. Es tritt dort eine Reihe von Schnee-Firn-Falten bis zu $8 \mathrm{~m}$ Höhe und mit einer Wellenlänge von etwa $100 \mathrm{~m}$ auf. Durch Wiedergefrieren von Schmelzwasser bildete sich im Sommer ${ }_{1952-53}$ entlang einer dieser Falten eine einzigartige Eisschicht. Etwa 2300 Eiskörner von Stellen entlang dieser Schicht wurden ausgemessen. Die Ergebnisse zeigen folgendes:

(1) Der mittlere Durchmesser der Eiskörner wechselt von 4,5 $\mathrm{mm}$ im Eis am Faltenscheitel bis zu 2,5 $\mathrm{mm}$ in der Zone maximaler Scherspannung und/oder in Gebieten mit starkem Gehalt an Luftblasen.

(2) Der grosse Korndurchmesser am Scheitel wird auf die stärkere Sonneneinstrahlung zurückgeführt, die dort infolge der Nähe zur Schneeoberfläche von 1958-59 und wegen der benachbarten Lage zur Oberfläche der exponierten Spaltenwand herrscht.

(3) Das Gebiet maximaler Scherspannung, das durch kleinere Korngrössen und Sekundärfalten gekennzeichnet ist, liegt annähernd in der Mitte zwischen Scheitel und Trog.

(4) Die Körner im Trog sind infolge geringerer Spannung grösser als solche in der Scherzone und kleiner als solche am Scheitel wegen ihrer tieferen Einbettung und wegen des Vorhandenseins einer Spaltenbrücke, die dort alle direkte Strahlung abschirmt.

(5) Das Wachstum der Eiskörner wird daher von der Temperatur, der Spannung und dem Grad der Verunreinigung bestimmt. 


\section{INTRODUCTION}

A highly deformed area in the Ross Ice Shelf near the Bay of Whales (Fig. I) was investigated by a group from the University of Michigan during the $195^{8-59}$ Antarctic summer

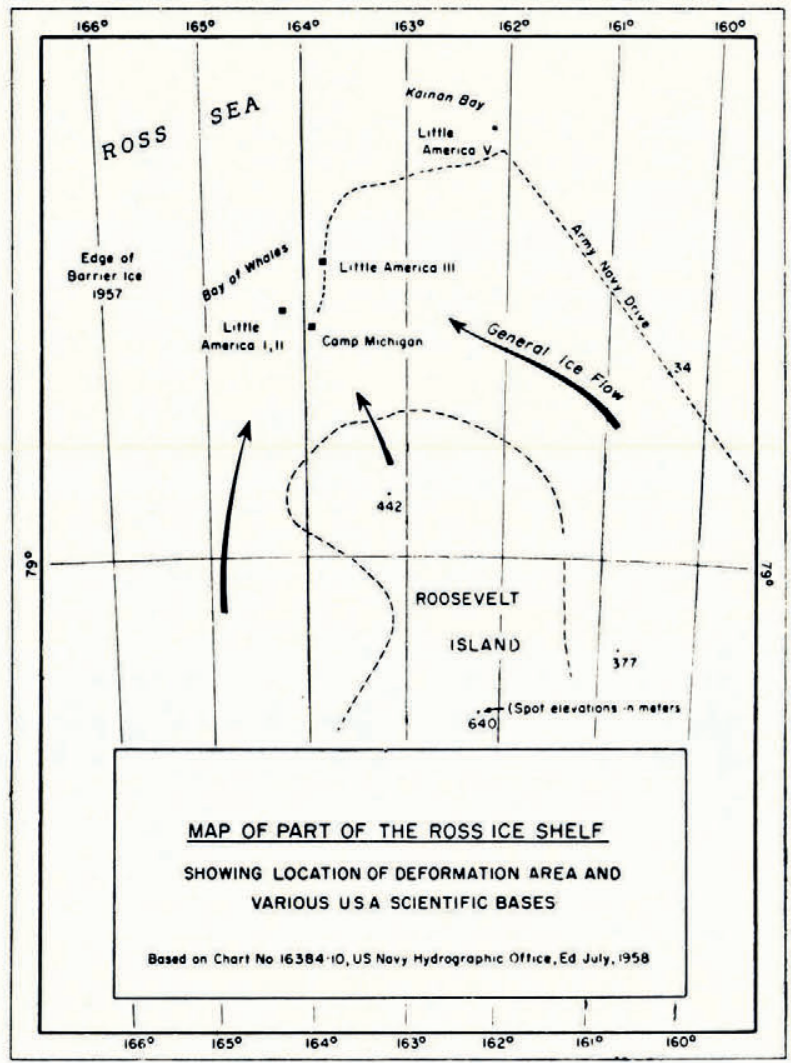

Fig. I. Map of part of the Ross Ice Shelf showing the location of the deformation area

season. A series of snow-firn folds up to $8 \mathrm{~m}$. high and with a wavelength of approximately $100 \mathrm{~m}$. occurs here as a result of the ice shelf flowing around Roosevelt Island and merging near the Bay of Whales (Figs. 2 and 3). Along one of these folds a unique ice layer, exposed along a crevasse wall, was traced from the trough across to the opposite limb of the fold and was examined in detail (Figs. 4 and 5 ).

Ice layers in this area of the Ross Ice Shelf are not common. In the past there has even been some question as to the origin of those that do exist. Wade (1945, p. 167), for example, noted such bands and lenses near here in I94I and remarked that "at first it was thought that the clear ice bands were formed during the summer when the air temperature was near or even above the freezing point and that the clear ice crust was formed from melt water". Since he did not observe such layers forming under these conditions and since many of the ice layers were in winter accumulation layers, he concluded that the ice formed when supercooled, moisture-laden clouds came in contact with the surface during the winter season. 
Because of percolation possibilities, however, the presence of such layers in winter horizons does not preclude their formation during the summer season. Ice pipes, which presumably conducted melt water from near the snow surface, were found in the wall of pit No. 4 (Fig. 5) excavated in the trough of one of these folds. (For the stratigraphic interpretation see figure I 3 in Giovinetto's contribution in Zumberge and others (1960).) It is evident that the ice layers this writer studied were formed by the refreezing of melt water.

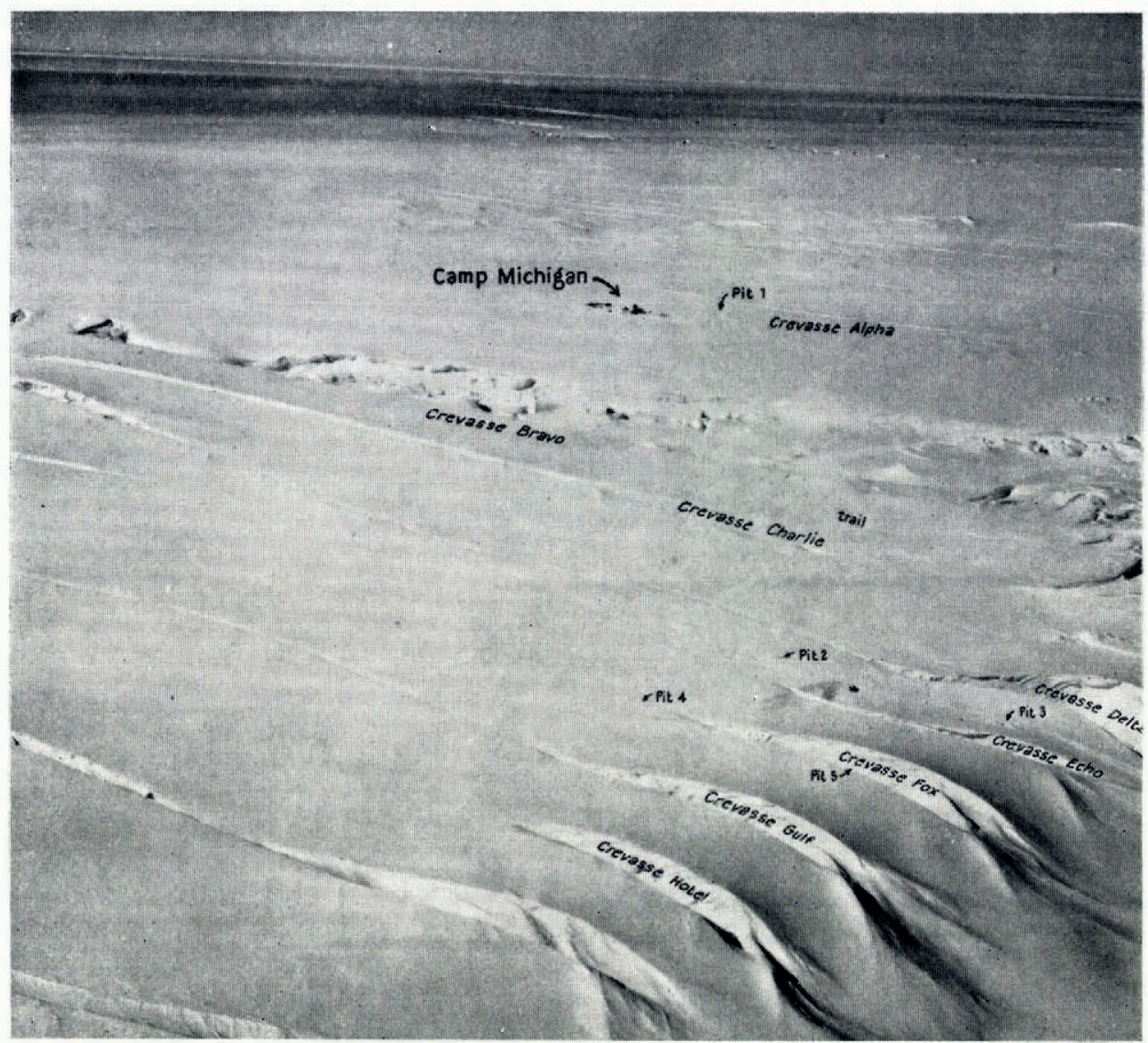

Fig. 2. Oblique view of the deformation area

From all indications, including the observation of the pipes in pit No. 4, the refreezing occurred between 5 and $15 \mathrm{~cm}$. below the $195^{8}-59$ surface. Eventually, however, (probably within a year) the stresses that had been continuously present in the entire fold reached a critical value in increasing portions of the layer which was sufficient to cause recrystallization. Exactly what this critical limit for ice is, is not known, but according to Steinemann (I954, p. $4 \mathrm{IO})$ if there exists a definite critical limit of shear stress, it must be less than $0.2 \mathrm{~kg} . / \mathrm{cm} .^{2}$.

\section{Factors of Recrystallization}

Subsequent recrystallization has occurred in varying amounts all along the studied layers. The degree of recrystallization has been controlled by (I) the amount of solar radiation and, 


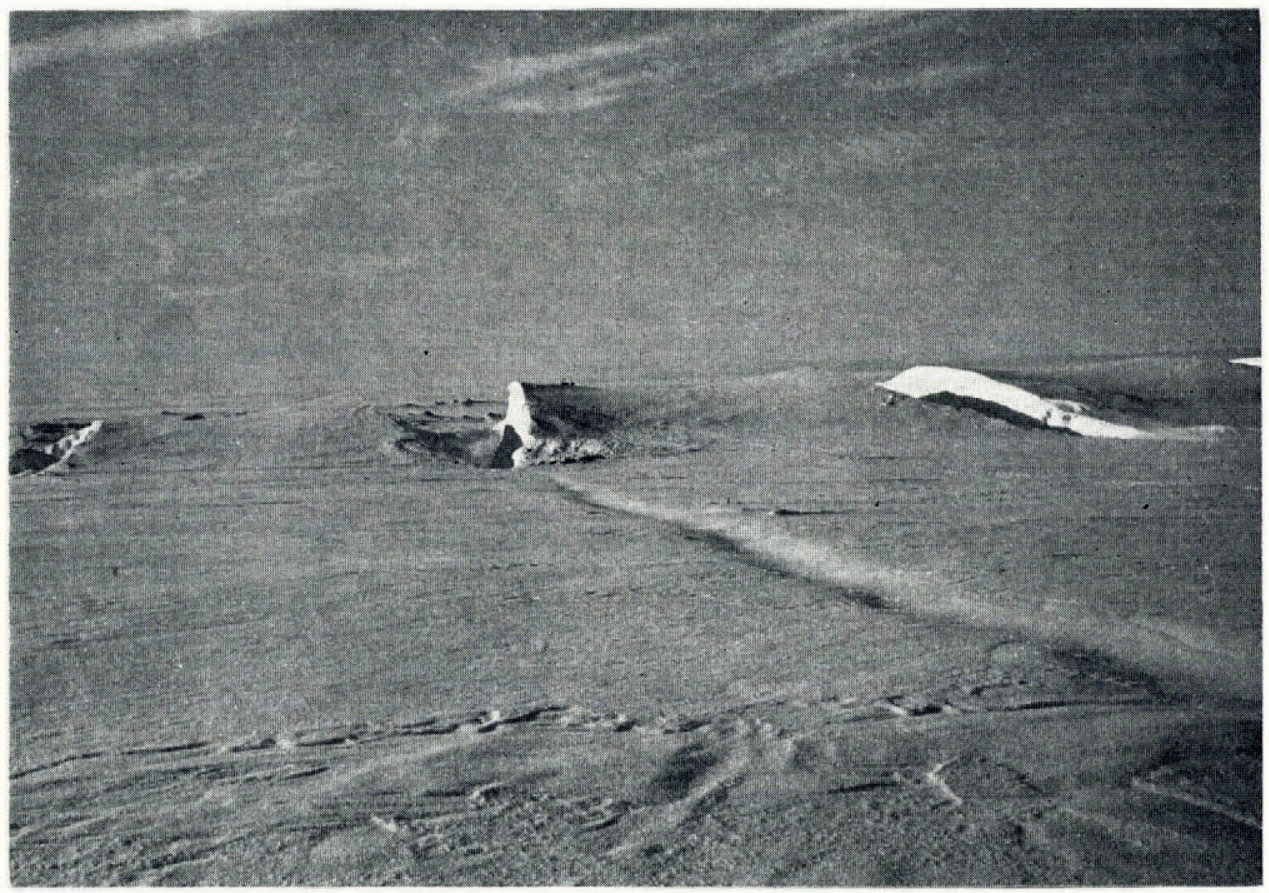

Fig. 3. Crevassed anticline showing saddles along its crest

therefore, the temperature, (2) the stress, (3) the orientation and (4) the percentage of air bubbles (as impurities). Because all the ice in the layer formed during the same interval, the time factor is a constant.

\section{Temperature}

Temperature is probably the most widely recognized factor in the process of crystal growth. It is surprising, therefore, that much of the basic information on the relationship of temperature to crystal size has been derived from a study of metals. In the case of a metal of hexagonal symmetry such as zinc or magnesium it has been demonstrated that when a rolled and, therefore, stressed sheet composed of either of these metals is heated for a short time new crystal nuclei form in regions of high internal stress and begin to grow at the expense of existing crystals. If such heating is sufficiently prolonged a process of crystal growth occurs which generally results in an increase in the average size of the individual crystals (Perutz and Seligman, I939, p. 355-59).

If ice is temporarily placed under a stress which is later removed, the resulting growth in grain-size will be very much retarded if the temperature is below $-5^{\circ} \mathrm{C}$. and almost negligible if the temperature is below $-10^{\circ} \mathrm{C}$. (Rigsby, r96o, p. 604).

\section{Stress}

In contrast to temperature, high stress appears to have an adverse effect on the growth of ice crystals. When Bader and others (1939, p. 54-55) attempted to make the first correlation between stress and the orientation of ice crystals, they discovered that while the ice was being subjected to shear stress, the crystals were observed to grow. Perutz (1940, p. 133-34) 


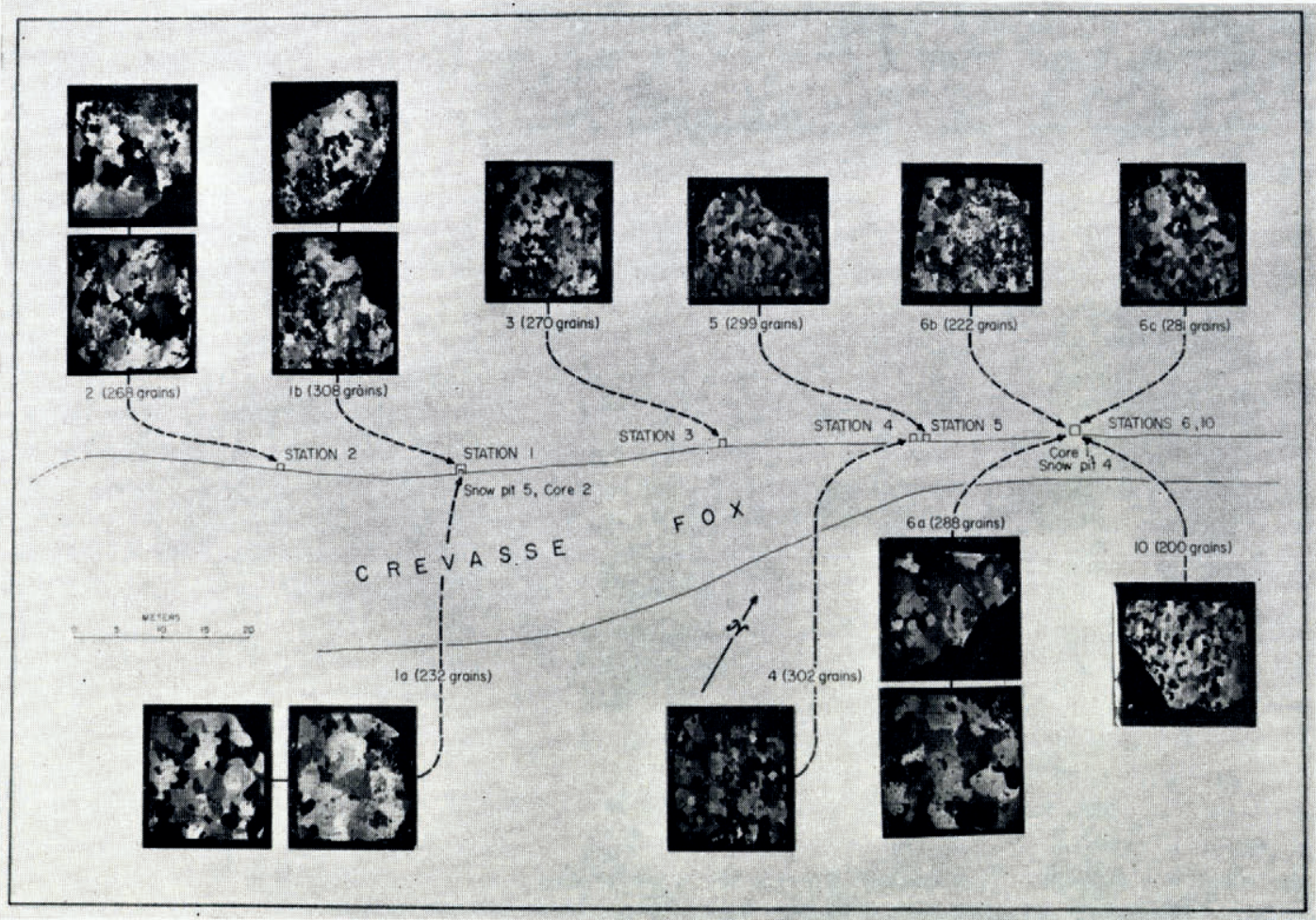

Fig. 4. Plan view of "Crevasse Fox" showing station sites and ice thin sections (each section is about $5 \mathrm{~cm} .{ }^{2}$ )

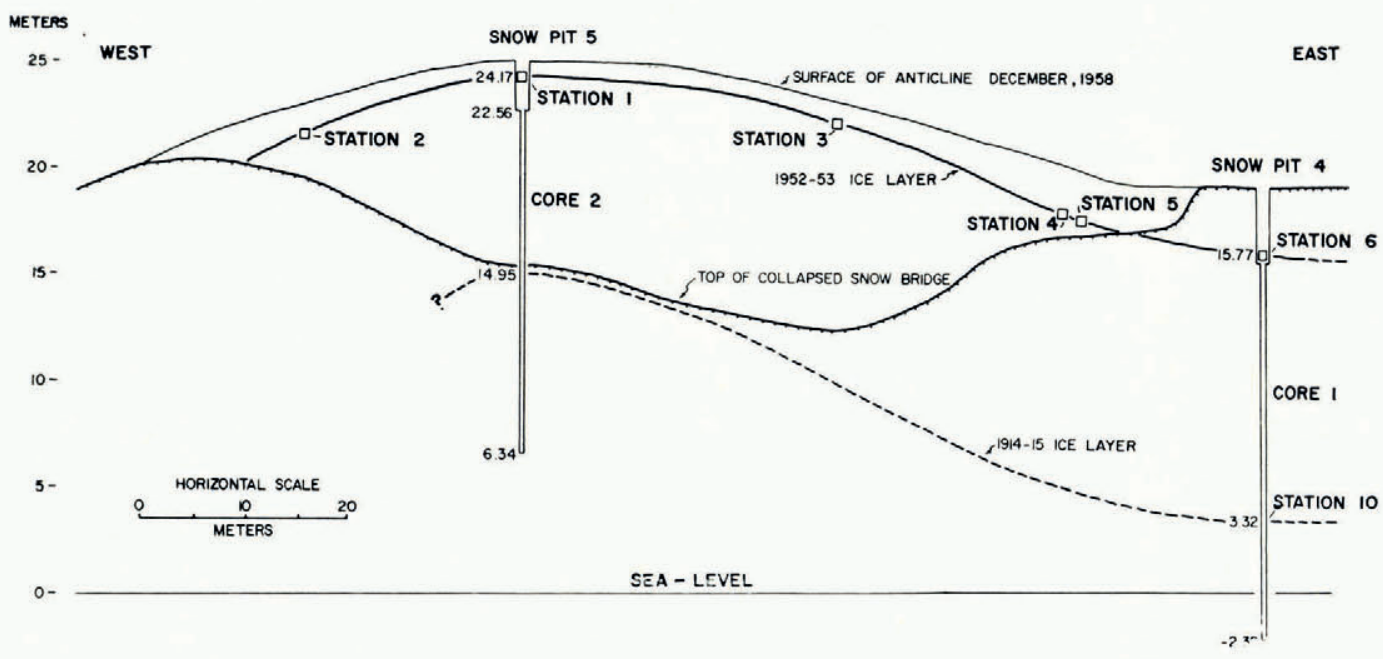

Fig. 5. Cross-section of "Crevasse Fox" showing station sites and positions of ice layers 
corroborated the observation of Bader and others, and stated that an increase in grain-size is the inevitable result of strain. More recently, Steinemann (1958, p. 46-5o) was able to produce such an increase during recrystallization under a load, "primary parakinematic recrystallization", as well as the normal increase in crystal size when the load was released, "post-kinematic recrystallization".

Shumskiy (1958, p. 246) repeatedly showed that recrystallization under stress results in a reduction not an increase in the average grain-size. [Kamb] (196o, p. 365) related the fine-ice layers in the Blue Glacier to zones of high stress and the coarse-ice layers to zones of very weak stress, and both Glen (1958, p. 259) and Seligman (1949, p. 262) further demonstrated the close relationship between high stress and small grains.

The answer to this difference of opinion is in the temperature of the ice at the time of the experiments. It has already been noted that ice recrystallizes readily near the melting point and the above experiments which resulted in a growth in crystal size upon the application of stress were evidently not temperature-controlled. Bader and others (1939, p. 53-55), for example, subjected their ice to average stresses of $4.5 \mathrm{~kg} . / \mathrm{cm} .^{2}$, but at an initial room temperature of only $-4^{\circ}$ to $-5^{\circ} \mathrm{C}$. Since an increase in pressure of 100 atmospheres will raise the temperature approximately $\mathrm{I} \cdot \mathrm{I}^{\circ} \mathrm{C}$. and will lower the freezing point $\mathrm{I}^{\circ} \mathrm{C}$., the ice used by Bader and others at the time of their experiments was close to the melting temperature. Consequently, it appears that any increase in crystal size under conditions of moderate to great stress is the result not of the stress factor but of the closely related temperature factor.

Release of stress will cause an increase in crystal size. Seligman (1950, p. 380-8I) observed an eight-fold increase in the crystal size in blocks that had been cut from ice tunnels in Switzerland and left standing for decoration. He attributed this increase to the release of stress, but he also admitted that the better circulation of air around the blocks might have favored the growth. To provide more positive evidence of recrystallization after release of stress, Glen (1958) subjected thin sections of ice to varying amounts of stress and found that the sections that had been under stresses of $8.5 \mathrm{~kg} . / \mathrm{cm} .{ }^{2}$ had smaller crystals than those that had been under stresses of $3.6 \mathrm{~kg} . / \mathrm{cm} .^{2}$. Ice that had been under stresses of over 5.0 $\mathrm{kg}$. $/ \mathrm{cm} .^{2}$ actually recrystallized again in the thin section, which indicated to Glen (1958, p. 259) that large stresses had been trapped in the deformed sections.

It has frequently been assumed that ice will flow faster under a high hydrostatic stress. The basis for this hypothesis seems to have been the proposal of an extrusion flow theory by Demorest (1943). He assumed that ice at depth would flow faster as a result of the weight of the overlying ice thus causing the ice to become more plastic. True, it is generally recognized that shear stresses at the bottom of a glacier are greater than those near the top, but it was not known what effect the hydrostatic pressure had on the shear forces. Rigsby (1958[a], p. 276-77) determined that if the temperature difference between the ice temperature and the melting point were kept constant there would be little or no effect by increased hydrostatic pressure on the rate of deformation. With an increase of $35^{\circ}$ atmospheres in the hydrostatic pressure, the temperature was raised $4^{\circ} \mathrm{C}$. and the melting point was lowered more than $2 \cdot 5^{\circ} \mathrm{C}$. It was concluded that the temperature is far more important than the hydrostatic pressure in the regulation of the deformation rate and, hence, the rate of recrystallization (Rigsby, 1958[a], figs. 7-10, p. 276).

Steinemann (1958, p. 32) studied the effect of hydrostatic pressure on the rate of shear strain on specially shaped rings of ice and concluded that up to go atmospheres pressure (the limits of his experiment), hydrostatic pressure had no direct effect on the plastic properties of polycrystalline ice. The conclusion is, therefore, that since the ice layer near "Camp Michigan" was under a normal pressure ranging from $\mathrm{I}_{4} \mathrm{I} \cdot 73 \mathrm{~g} . / \mathrm{cm}^{2}{ }^{2} \mathrm{I}_{1} \mathrm{I}_{4}$ atmospheres including the I atmosphere pressure at the surface) at the trough of the fold to only $39 \cdot 84 \mathrm{~g} . / \mathrm{cm} .^{2}(\mathrm{I} \cdot \mathrm{O} 4$ atmospheres) at the crest (computed from data of Giovinetto, figures I 3 -I 4 in Zumberge and others ( 1960$)$ ), the effect of hydrostatic pressure on this ice layer can be disregarded completely. 


\section{Orientation}

More pertinent, perhaps, than a general relationship between stress and recrystallization is the combined relationship between orientation, stress and recrystallization. Steinemann [1956] made a series of observations on the preferred orientations produced by compression and found that recrystallization of grains under such compression favored those grains whose basal planes were $45^{\circ}$ to the compression direction, i.e. parallel to the plane of maximum shear. Conversely, crystals orientated with their basal planes perpendicular to the active shear plane are under the greatest stress and will therefore recrystallize the most rapidly (Shumskiy, I958, p. 245), and "crystals having the right orientation for yielding to stresses by glide along their basal planes would have a higher energy than others which cannot yield; the former would therefore have a tendency to grow at the expense of the latter by molecular exchange across the crystal boundaries" (Perutz, I940, p. I $32-33$ ).

\section{Impurities}

Another important factor which regulates the rate of recrystallization is the amount of impurities present in the ice. Cahn (1949, p. I34) discovered that the greater the purity of zinc crystals (hexagonal) the easier they recrystallize. Nickelsen and Gross (1959, p. 285) found that quartz, when it is surrounded by other minerals, commonly shows poor preferred orientation which, in turn, indicates a lack of recrystallization. As for ice, Rigsby (196o, p. 6o2) noted that "bubbles apparently inhibit the growth of crystals even at the melting temperature" and suggested that either the bubbles interfered with the migration of crystal boundaries, or "possibly the strains are relieved readily by migrating to a bubble-ice boundary so there is no need to recrystallize". Ice from the "Camp Michigan" area seems to substantiate Rigsby's observation, for there are frequently found only very small crystals in the bubbly portions of otherwise coarse-grained, bubble-free ice (see for example thin sections $\mathrm{Ib}$, Figure 4 ). It is further suggested that the relief of strain by the bubbles is more important than the prevention of migration of the crystal boundaries.

\section{Time}

Very little information is available on the importance of time on recrystallization, but many casual observations have been made which note that it is a real factor. For example, Seligman (1949, p. 262) stated that crystals generally increase in size from the source to the snout of a glacier and that the longer the glacier, the larger the crystals at its end. Furthermore, where stress is at a minimum, usually in the stagnant ice at the snout, the ice crystals are larger than those in the stressed ice of the actively flowing ice mass. He surmised from these observations that "crystal growth is, to a greater or less extent, dependent upon time". Rigsby (I $95^{8}$ [b], p. 357) concluded that "crystal size increases with temperature and time in glaciers in the inactive or stagnant state, whereas the size decreases with increasing strain-rates of the more active glaciers".

A totally contrasting idea was proposed by Demorest, but it was not fully elucidated at the time of his death in 1942 . He maintained that under stress a crystal is deformed and often bent. When this occurs, some undulatory extinction will result. With further stress the lattice may become energized to an unstable condition and immediately there will occur a rapid re-organization of the lattice, which Demorest (1953, p. 202) termed "instantaneous recrystallization". Glen (1953) agreed that rapid recrystallization does in fact occur, but not instantaneously! Grains under conditions assumed by Demorest grow "at a definite, and sometimes quite slow rate". Knopf (I953) claimed, however, that the recrystallization was actually instantaneous as was illustrated by time-lapse photography which showed recrystallization occurring within a period of a "few minutes" when the ice was near the melting point. Thus, 
temperature is again important, but instantaneous recrystallization appears to have some support. As a matter of fact, the recrystallization of the studied ice layer near "Camp Michigan" (after initial solidification) probably was instantaneous. However, subsequent recrystallization of the ice at the crest has been and is most likely the result of migrational recrystallization.

\section{Grain-size Analyses}

\section{Previous work}

The efficacy of two-dimensional size analysis of grains has been questioned by many researchers. Bader ( $195 \mathrm{I}$, p. 525), for example, noted that isolated rubbings of stagnant ice at the front of the Malaspina Glacier in Alaska suggest an average grain-size of only a few inches, which is a great underestimate because the shape of those grains is very long and exceedingly complex. In order to attempt a correlation of grain shapes and sizes Bader made a series of 26 rubbings at $0.2 \mathrm{in}$. $(0.5 \mathrm{~cm}$.) intervals and even then he found difficulty in correlating the grains from one rubbing plane to the next.

Fortunately, not all ice masses are composed of such complexly shaped grains and, therefore, if it can be determined that a mass is composed of more or less equant grains, twodimensional measurements may be useful. Nevertheless, it must be remembered that a single plane, whether it be represented by a rubbing or an actual thin section, will only by coincidence intersect the maximum diameter of a given grain. Consequently, an average observed grain-size in the section will, by necessity, be less than the actual average grain-size.

Seligman (1949, p. 256) accepted this deficiency as unimportant as long as relative results could be obtained. He therefore employed a method of the least circle diameter using standard root mean square diameters of $0 \cdot 25,0 \cdot 4,0 \cdot 6, \mathrm{I} \cdot \mathrm{o}, \mathrm{I} \cdot 6,2 \cdot 5,4 \cdot 0,6 \cdot 3$ and $\mathrm{I} 0 \cdot 0 \mathrm{~cm}$. in order that there be a constant ratio between each size and the next. He applied the measurements to rubbings of ice blocks from various glaciers in the Alps.

Ahlmann and Droessler (1949) preferred to measure the longest and the shortest axes of the grains in a section and to compute the area from these data. Boyé and Cailleux (I954) employed both methods and concluded that since the results were reproducible by both methods and since the latter involved more time, the root mean square method was more desirable.

On the basis of Seligman's studies (1949, p. 265) the following conclusions were reached:

"I. The crystal size observed at or near the glacier surface of an Alpine glacier shows an increase from bergschrund to snout. [Probably as a result of the factors of temperature and time.]

2. In active ice the crystals of the tongue are smallest on the lines of fastest flow, that is normally in the centre of the stream. They increase gradually towards the margins [where the stress is less and where the air content is less].

3. The longer the glacier, the larger the crystals. [As a result of a greater amount of time for the crystals to grow.]

4. The steeper the glacier, the smaller the crystals. [Due to faster flow and therefore greater stress.]

5. The relationships of crystal size to length of travel and to glacier speed indicate that while time must influence crystal growth in active ice there are probably other agencies as well.

6. Glacier movement may cause crystal growth by local shear stresses and by local pressure variations.

7. Crystals grow to very large size in dead ice even in the absence of stream flow [through migrational recrystallization with the aid of the temperature and the time factors]. 
8. Low temperatures retard crystal growth; warmth stimulates it even when no melt water is present.

9. The freezing of melt water does not play any important part in the growth of the crystals of pure ice."

Each of these observations have since been corroborated through subsequent research both in the field and in the laboratory. (See, for example, MacGregor (195I, p. 569); Ahlmann and Droessler (I949, p. 274); Shumskiy (1958, p. 245); Rigsby (1958[b], p. 357); Cahn (I949, p. I40); and Schytt (1958, p. I28-45).)

\section{"Camp Mighigan" Grain-size Analyses}

A preliminary examination of the thin sections from the "Camp Michigan" area indicated that in some there appeared to be a direct correlation between the average grain-size and the amount of solar radiation which the ice had received. More detailed studies on the size parameters were therefore undertaken in an effort to evaluate them statistically.

A series of circles representing the scale of the actual grains in terms of $0.25,0.4,0.6$, $\mathrm{I} \cdot \mathrm{o}$ and $\mathrm{I} \cdot 6 \mathrm{~cm}$. (root mean square diameters) was superimposed on $35 \mathrm{~mm}$. colored slide projections of the ice thin sections and the number of grains corresponding to each circle diameter was recorded. Every grain in each section was measured to eliminate the possibility of preferential analysis. From twelve thin sections, a total of 2,294 grains was measured, and from the results the skewness, $Q_{1} Q_{3} / M d^{2}$, the Trask cocfficient of sorting, $\left(Q_{3} / Q_{1}\right)^{\frac{1}{2}}$, and the parameters necessary for those calculations were recorded.

\section{Median diameter}

Table I is a summary of the crystal-size data and Figures 6-8 depict graphically the relationships between the distance from the crest of the fold and the respective median diameters, the percentage of grains larger than $\mathrm{I} \cdot 0 \mathrm{~cm}$. in diameter, the sorting coefficients and the depths below the surface. From these data several conclusions have been drawn.

Table I. Location and Statistical Analysis of Grain-size Data

\begin{tabular}{|c|c|c|c|c|c|c|c|c|c|c|}
\hline $\begin{array}{l}\text { Thin section } \\
\text { Depth below }\end{array}$ & I a & $\mathrm{Ib}$ & 2 & 3 & 4 & 5 & $6 \mathrm{a}$ & $6 \mathrm{~b}$ & $6 c$ & I0 \\
\hline snow surface $(\mathrm{cm})$. & $83 \cdot 0$ & $83 \cdot 5$ & $141 \cdot 5$ & $103 \cdot 5$ & $190 \cdot 0$ & $204 \cdot 0$ & $317 \cdot 5$ & $311 \cdot 5$ & $317 \cdot 5$ & ${ }^{1} 562 \cdot 5$ \\
\hline $\begin{array}{l}\text { Distance from } \\
\text { crevasse wall }\end{array}$ & $\begin{array}{c}0 \cdot 0 \\
\text { to }\end{array}$ & $\begin{array}{l}37 \cdot 5 \\
\text { to }\end{array}$ & $\begin{array}{l}15 \cdot 0 \\
\text { to }\end{array}$ & $57 \cdot 75$ & $\begin{array}{l}7 \cdot 5 \\
\text { to }\end{array}$ & $\begin{array}{l}30 \cdot 0 \\
\text { to }\end{array}$ & $\begin{array}{l}0 \cdot 0 \\
\text { to }\end{array}$ & $\begin{array}{c}82 \cdot 5 \\
\text { to }\end{array}$ & $\begin{array}{l}165 \cdot 0 \\
\text { to }\end{array}$ & $\begin{array}{c}15 \cdot 0 \\
\text { to }\end{array}$ \\
\hline Percentage of grains & $7 \cdot 5$ & $5^{2 \cdot 5}$ & $22 \cdot 5$ & $60 \cdot 0$ & $15 \cdot 0$ & $37 \cdot 5$ & $7 \cdot 5$ & $90 \cdot 0$ & $172 \cdot 5$ & $22 \cdot 5$ \\
\hline $\begin{array}{l}\text { less than } 0.25 \mathrm{~cm} \text {. } \\
\text { Percentage of grains }\end{array}$ & I0. 86 & $3^{6} \cdot 55$ & $23 \cdot 5^{8}$ & $37 \cdot 82$ & $34 \cdot 27$ & $33 \cdot 87$ & $20 \cdot 65$ & $32 \cdot 16$ & $28 \cdot{ }^{1} 5$ & $52 \cdot 68$ \\
\hline $\begin{array}{l}\text { larger than } 1.0 \mathrm{~cm} \text {. } \\
\text { Median diameter }\end{array}$ & $26 \cdot 63$ & $12 \cdot 19$ & $12 \cdot 59$ & $3 \cdot 03$ & $4 \cdot 84$ & $I \cdot 6 I$ & $13 \cdot 76$ & $3 \cdot 5^{\mathrm{I}}$ & $5 \cdot 34$ & $0 \cdot 31$ \\
\hline $\begin{array}{l}\text { (cm.) } \\
\text { Sorting }\end{array}$ & $0 \cdot 45$ & $0 \cdot 3^{I}$ & $0 \cdot 3^{8}$ & $0 \cdot 30$ & $0 \cdot 30$ & $0 \cdot 3^{1}$ & $0 \cdot 3^{8}$ & $0 \cdot 29$ & $0.3 \mathrm{I}$ & $0 \cdot 24$ \\
\hline coefficient $(S o)$ & $\mathrm{I} \cdot 39$ & $I \cdot 47$ & $I \cdot 40$ & I $\cdot 37$ & $1 \cdot 37$ & I $\cdot 36$ & I $\cdot 39$ & I $\cdot 26$ & $\mathrm{I} \cdot 29$ & $1 \cdot 28$ \\
\hline Skewness & $-0 \cdot 98$ & $-\mathrm{I} \cdot 04$ & -0.89 & $-0.9^{I}$ & $-\mathrm{I} \cdot \mathrm{OI}$ & $-0 \cdot 9^{\circ}$ & $-0.9^{2}$ & $-\mathrm{I} \cdot 08$ & $-\mathrm{I} \cdot 00$ & $-\mathrm{I} \cdot \mathrm{I} 5$ \\
\hline
\end{tabular}

First, it is apparent that proximity to the open crevasse wall along which the layer was exposed is a very important factor in the control of ice crystal growth. Figure 4 illustrates two separate sets of evidence which verify this conclusion. First, thin sections ra, from the crevasse wall, contain larger crystals than sections $\mathrm{Ib}$ which are located $37 \cdot 5$ to $52 \cdot 5 \mathrm{~cm}$. in from the crevasse wall at the same station on the fold. The former sections have a median diameter of $0.45 \mathrm{~cm}$. while 


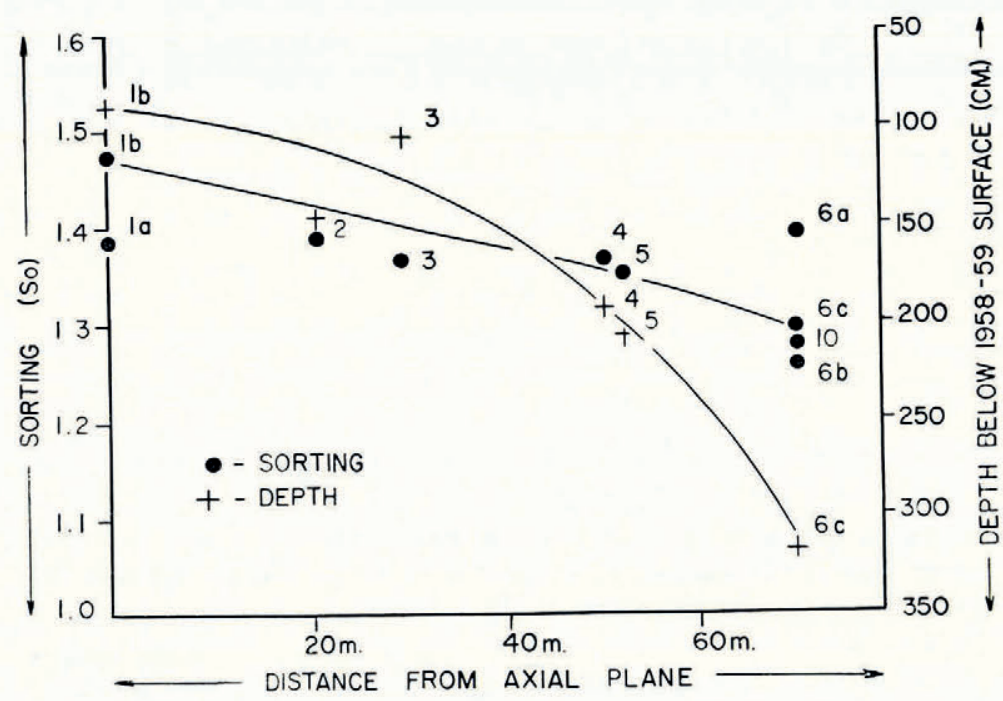

Fig. 6. Relationship between sorting and depth of ice thin-section grains with distance from crest of anticline

that of the latter sections is only $0.3 \mathrm{I} \mathrm{cm}$. Secondly, thin sections $6 \mathrm{a}$ which are also from the crevasse wall, but in the trough of the fold rather than at the crest, have a median diameter of $0.38 \mathrm{~cm}$. and thin section $6 \mathrm{c}$ which is from a point 165.0 to $172.5 \mathrm{~cm}$. in from the crevasse wall at station 6 has a median diameter of only $0 \cdot 3^{1} \mathrm{~cm}$. At both lateral extremes of the fold there is evidence that the ice at the crevasse wall receives more radiation than ice within the wall. The result is that ice under slightly higher temperature during the warmer season grows more rapidly than the ice that is more protected from radiation.

In addition to the distance from the wall, the depth below the snow surface is important because this also regulates the amount of radiation that the ice layer will receive. This explains why

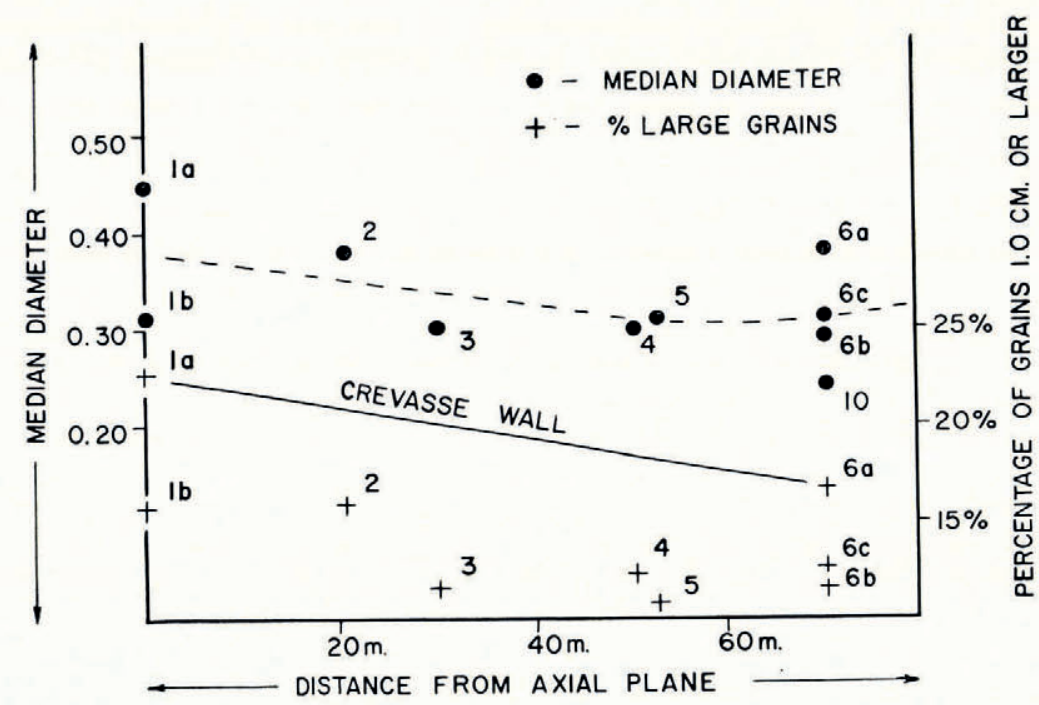

Fig. 7. Relationship between grain-size and distance from crest of the anticline 


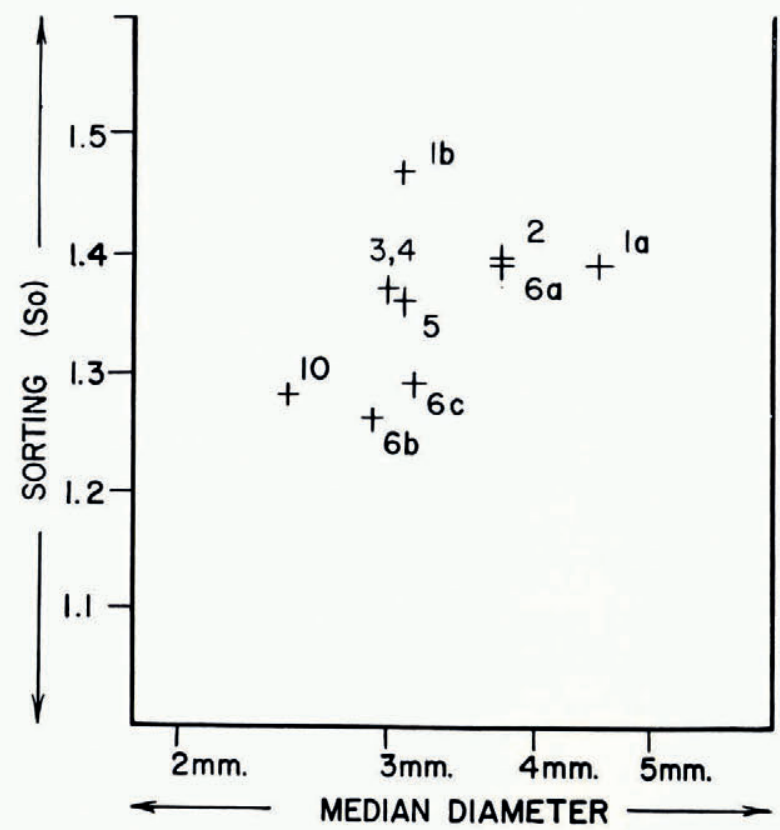

Fig. 8. Relationship between sorting and median diameter of ice grains

sections Ia, which are only $83 \mathrm{~cm}$. from the surface, have a larger median diameter than sections 6 a which are $317.5 \mathrm{~cm}$. below the surface; the former sections are both closer to the snow surface and are from the crevasse wall.

The ice grains in sections $6 \mathrm{a}$ are controlled by one other radiation factor; the crevasse at this location is covered with a snow bridge which prevents direct radiation. However, the sections do have a relatively large median diameter and they are at the crevasse wall. The larger diameter must be explained as the result of circulating relatively warm air (during the summer season) even though the crevasse is not open to direct radiation. The snow forming the bridge is very permeable and movement of air during summer storms, when the temperature is usually higher than normal, is perceptible within the covered portion of the crevasse. The high median diameter of sections ra is explained, therefore, both by the proximity to the open wall of the crevasse and by the very shallow depth below the snow surface. The ice along the wall, but beneath the snow bridge, has large grains only because it is exposed along the crevasse wall. It may be argued, however, that the large grains in the trough area may be the result of release of stress when the crevasse opened. But, the ice layer was traced through the lower portion of the snow bridge at this location, indicating that the crevasse was open at the time that the layer formed and that the bridge was in the initial stages of formation; the stress had already been released, if it is assumed that crevasse formation releases stress!

If exposure to radiation is the only controlling factor in the growth of large grains, it should be expected that other thin sections which are also from points close to the crevasse wall should also have large median diameters. Such is not the case. Although none of the sections displayed in Figure 4 are from the actual surface of the wall, several are from the zone that should be affected by direct radiation. For example, thin section 5 is from ice located approximately three-quarters of the distance from the crest to the adjacent trough of the fold and $30 \cdot 0$ to $37 \cdot 5 \mathrm{~cm}$. in from the wall. Despite this short wall depth, the section has a median diameter of only $0.3 \mathrm{I} \mathrm{cm}$., the same diameter as sections from the crest and the trough which 
are as much as $172 \cdot 5 \mathrm{~cm}$. in from the wall. For its location, thin section 5 has a smaller median diameter than it should when compared to the others. This is explained by the greater shear stress on the ice layer at this point on the fold.

Theoretically, such a fold, under a relatively constant stress from outside the area, is under varying stress from within. The surface at the crest of the anticline, for example, will be under a negative compressional stress and a positive tensile stress, whereas the same surface in the trough of the adjacent syncline will be under a positive compressional stress and a negative tensile stress. Consequently, somewhere between the crest and the trough there should be a point or area where compression is equal to tension. This location should reflect a condition of pure shear. Under such stress conditions growth of ice grains is inhibited (see p. I 96). Because ice from station 5 has such a small median diameter it may be near this zone of pure shear.

Station 4 , immediately up-slope from station 5 , not only has the highest degree of preferred orientation of all the stations in the layer (8-9 per cent per I per cent area) but it is also in the zone of secondary folding (Fig. 9). This seems to imply that station 4 is closer to the theoretical zone of pure shear than is station 5 .

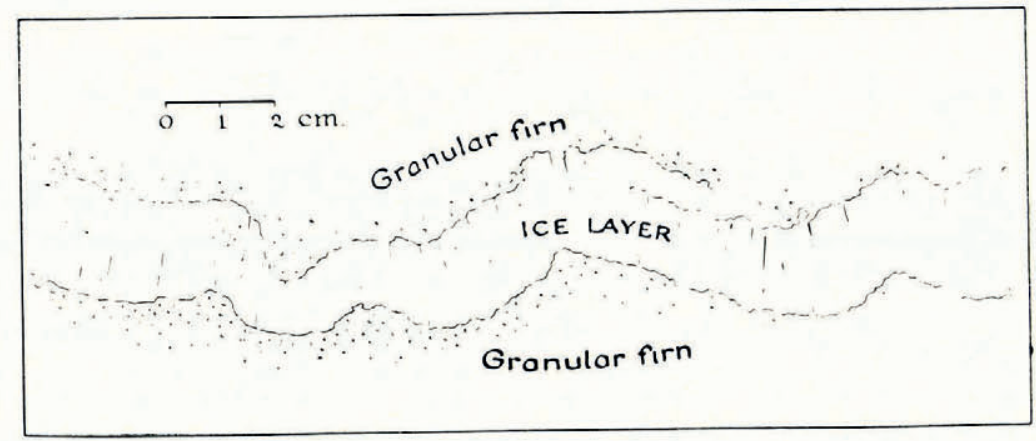

Fig. 9. Secondary folds in the 1952-53 ice layer near station 4

According to Kehle's strain data (Zumberge and others, I96o), the stresses across the fold at "Crevasse Delta", approximately $220 \mathrm{ft}$. (67 m.) south of "Crevasse Fox", are not simple, even though the average strain for the entire area indicates that the strain in the fold approaches pure shear, i.e. the compressional strain is equal to the tensile strain. Strain values that were measured on the vertical wall of another crevasse in this same anticline illustrate the relative movements in the crest and the trough (figure 26 in Kehle's contribution in Zumberge and others (1960)). The crest is expanding upward and the trough is being compressed downward. Deviations from this general tendency can be clearly seen in that figure.

In summary, the ice layer at the crest has undergone an increase in crystal size because it was exposed to direct radiation; the same layer in the trough has also undergone an increase, but as a result of the restricted circulation of relatively warm air during summer seasons.

The layer in the vicinity of the secondary folds (thin section 4) did not undergo this increase in grain-size, because at the time of recrystallization, which probably was more or less instantaneous, the grains became preferentially orientated and were in equilibrium both with each other and with the shear stress, which is at a maximum here. There was a minimum of 
growth of the favorably orientated grains at the expense of those which were less favorably orientated; the grain-size was already adjusted to the stress conditions.

\section{Sorting}

Figure 6 shows that the sorting of the ice grains becomes more perfect with increasing depth, but there are many exceptions to this generalization. The ice in the layer at the crest, for example, has parts which are poorly sorted and some which are fairly well sorted; the parts away from the wall of the crevasse ( $\mathrm{I}$ b) have a sorting coefficient of only $\mathrm{I} \cdot 47$ an 1 are among the poorest sorted ice in the layer. Those sections from the same station, but at the wall (ra) have a more moderate sorting coefficient $(\mathrm{I} \cdot 39)$. Part of the answer to this difference probably lies in the fact the ice sections $\mathrm{Ib}$ contain abundant air bubbles which are not evenly distributed throughout the sections and which therefore have a varying effect on the rate of crystal growth; where the bubbles are most abundant, the grains are the smallest and, where bubbles are essentially absent, the grains are more uniform in size and larger.

Thin section 3 also contains bubbles, but it has a better sorting of grains $\left(S_{0}={ }_{1} \cdot 37\right)$ than the crest ice from the wall. The bubbles, however, are more evenly distributed and the crystal growth was apparently more uniformly inhibited. Thin sections 4 and 5 are also fairly well sorted $\left(S_{0}=\mathrm{I} \cdot 37\right.$ and $\left.{ }_{\mathrm{I}} \cdot 36\right)$ which reflects both the almost complete absence of bubbles and the high shear stress which seems to be present at these locations.

The sorting of the ice in the trough is much more difficult to explain, for since the sorting generally increases with increasing depth, this ice should theoretically be the best-sorted ice in the layer. Such is not the case. The deviation of the sorting coefficients within this station is as great as the total deviation of the remaining sections. The poorest-sorted sections are not the farthest from the crevasse wall, as was the case at the crest, but they are instead at the wall. Sections $6 \mathrm{a}$ have a sorting coefficient of slightly less than $\mathrm{I} \cdot 39$, whereas section $6 \mathrm{c}$ which is I $65^{\circ} \mathrm{O}$ to $\mathrm{I}_{72} \cdot 5 \mathrm{~cm}$. from the wall has a coefficient of $\mathrm{I} \cdot 29$. Furthermore, section $6 \mathrm{~b}$ which is intermediate in distance between the other two locations, has a coefficient of $1 \cdot 26$ and is the most perfectly sorted ice in the layer. Bubbles are abundant only in this last section and are uniformly distributed throughout the section. The variability of the sorting in the trough station is therefore probably the result of several factors, including the fact that the ice at this location is not under great stress and the sections from this station were taken over a greater distance from the open crevasse. There is also the possibility that this station demonstrates the fallacy of these measurements in that any or all of these sections might have been cut through an unrepresentative part of the layer. It has already been stated that the median diameter, as measured in these sections, is much less than the absolute median because the grains in the sections were measured in two dimensions only. Consequently, generalizations may be valid but specific answers are almost impossible because of the large errors inherent in this technique.

\section{Skewness}

There appears to be no significant trend of the values for skewness. They range from $0 \cdot 89$ at station 2 to $\mathrm{I} \cdot 08$ at station 6 with no regularity of the trend between the two localities. This parameter appears to be the least valuable of the statistical parameters.

\section{Statistical Data of the I914-I5 Ice Layer}

The only station not on the same continuous layer was No. Io (Fig. 5). The ice layer at this station was the most striking layer in the fold, for it was thicker ( 2 to $3 \mathrm{~cm}$.), deeper 
$(\mathrm{I}, 562 \mathrm{~cm}$.$) , and it was much older (formed in 1914) than the upper layer. The layer was$ accessible only by descending into the crevasse in the trough area where it was concealed by a snow bridge. Because of its location, the grain-size statistics of this layer are limited to this one station.

The most significant observation here was the fact that only o.3 per cent of the grains were larger than $\mathrm{I} \cdot \mathrm{O} \mathrm{cm}$. in diameter, in contrast to a minimum of 3.0 per cent in the younger layer (station 3 ). Furthermore, $5^{2} \cdot 7$ per cent of the grains were smaller than $0.25 \mathrm{~cm}$. in diameter, in contrast to a maximum of $37 \cdot 8$ per cent in the upper layer (station 3 ). A median diameter of $0.24 \mathrm{~cm}$. and a sorting coefficient of $\mathrm{I} \cdot 28$ appear to support the conclusion that the ice at this location is close to equilibrium with the factors which regulate crystal growth. The most important of these factors is temperature, which, because of the great depth and the protective cover of the snow bridge, remains relatively constant throughout the year. Because of the age of the layer, the ice has had a much greater length of time in which to adjust itself to the stress conditions. As a result, the ice grains at station ro are much more uniform in size than those in the ice of the $195^{2-} 53$ layer. As in the case of the younger layer, the skewness does not appear to be significant. This also may be the result of a lack of sufficient data.

\section{SumMary}

Grain-size has been shown to be directly related to the amount of radiation that the ice receives (controlled by the proximity to the snow surface and to the open crevasse), to the relative amount of shear stress to which the ice is subjected, and to the relative abundance of air bubbles in the ice.

One additional factor which has not been discussed here for lack of sufficient data is the thickness of the layer itself; some of the largest crystals were found in the thinnest parts of the layer and some of the smallest were in the thickest parts. For example, the ice from station I contained very large crystals but the layer averaged only $0.25 \mathrm{~cm}$. in thickness, whereas the layer at stations 4 and 5 was up to $3.0 \mathrm{~cm}$. thick and the crystals were among the smallest in the entire layer. One explanation for this variance in thickness is that the thinner parts represent a lateral percolation of the melt water away from those locations and the thicker parts represent a net accumulation of melt water. The data collected neither support nor disprove this hypothesis. The factors which determine the thickness of a layer apparently are even more numerous than those which regulate the size of the grain. Consequently, the phenomenon remains unexplained.

\section{Acknowledgements}

The field research for this investigation was financed through the USNC-IGY Glaciology Project 4.5 of the Arctic Institute of North America and was under the guidance of Dr. James H. Zumberge, Department of Geology, University of Michigan (presently President of Grand Valley State College, Michigan). Various stages of the data reduction were supported by USNC-IGY Glaciology Project 4. Io, administered by The Ohio State University Research Foundation, a National Science Foundation research grant (NSF-Gi2502), administered by Mount Union College, and most recently, a faculty research grant from the University of North Dakota. Much of the initial extraction of the ice would not have been possible without the co-operation of the other members of the Ross Ice Shelf Deformation Project: Mario Giovinetto, Ralph Kehle, Nolan Aughenbaugh and James Burnham. Appreciation for their assistance is gratefully recognized. This paper represents part of a dissertation submitted as partial fulfilment for the Ph.D. degree at the University of Michigan. It is a pleasure to 
acknowledge the valuable suggestions contributed by the members of my committee, particularly Drs. Donald F. Eschman and James H. Zumberge. Drs. Mark Rich and Walter L. Moore, Department of Geology, University of North Dakota, kindly offered advice and criticisms on this manuscript. Their assistance is greatly appreciated.

\section{$M S$ received 6 June 1963}

\section{REFERENCES}

Ahlmann, H. W., and Droessler, E. G. 1949. Glacier ice crystal measurements at Kebnekajse, Sweden. Journal of Glaciology, Vol. I, No. 5, p. 268-74.

Bader, H. 1951. Introduction to ice petrofabrics. Journal of Geology, Vol. 59, No. 6, p. 519-36.

Bader, H., and others. 1939. Der Schnee und seine Metamorphose, von H. Bader, R. Haefeli, E. Bucher, J. Neher, O. Eckel, C. Thams, P. Niggli. Beiträge zur Geologie der Schweiz. Geotechnische Serie. Hydrologie, Lief. 3. [Translated by J. C. van Tienhoven, U.S. Snow, Ice and Permafrost Research Establishment. Translation 14, 1954.] Boyé, M., and Cailleux, A. 1954. Inland ice crystal measurements at Eqe, West Greenland. Journal of Glaciology,
Vol. 2, No. 15, p. 324-30. Cahn, R. W. 1949. Recrystallization of single crystals after plastic bending. Fournal of the Institute of Metals, Vol. 76 ,
Pt. 2, p. 12 I-43.

Demorest, M. H. 1943. Ice sheets. Bulletin of the Geological Society of America, Vol. 54, No. 3, p. 363-99.

Demorest, M. H. 1953. Processes of ice deformation within glaciers. Fournal of Glaciology, Vol. 2, No. I3, p. $201-03$.

Glen, J. W. 1953. Comments on Dr. Demorest's paper. Journal of Glaciology, Vol. 2, No. 13, p. 2 i 9.

Glen, J. W. 1958. The mechanical properties of ice. I. The plastic properties of ice. Advances in Physics, Vol. 7 ,
No. 26, p. $254-65$.

Kamb, W. B. 1959. Ice petrofabric observations from Blue Glacier, Washington, in relation to theory and experiment. Journal of Geophysical Research, Vol. 64, No. i i, p. 1891-1909. [Kamb, W. B.] 1960. Ice fabrics on Blue Glacier. Transactions. American Geophysical Union, Vol. 41, No. 2, p. 360-67;
IGY Bulletin (Washington, D.C.), No. 34, p. 10-17.

Knopf, E. B. 1953. "Processes of ice deformation within glaciers" by the late Max Harrison Demorest. Fournal of Glaciology, Vol. 2, No. 14, p. 297. [Letter.]

MacGregor, A. G. 195 I. Ice crystals in glaciers compared with quartz crystals in dynamically metamorphosed sandstones. Fournal of Glaciology, Vol. I, No. 10, p. 564-71.

Nickelsen, R. P., and Gross, G. W. 1959. Petrofabric study of the Conestoga Limestone from Hanover, Pennsylvania. American Fournal of Science, Vol. 257, No. 4, p. 276-86.

Perutz, M. F. 1940. Mechanism of glacier flow. Proceedings of the Physical Society (London), Vol. 52, No. 289,
p. ${ }_{132-35}$.

Perutz, M. F., and Seligman, G. 1939. A crystallographic investigation of glacier structure and the mechanism of glacier flow. Proceedings of the Royal Society, Ser. A, Vol. 1 72, No. 950, p. 335-6o.

Rigsby, G. P. 1958[a]. Effect of hydrostatic pressure on velocity of shear deformation of single ice crystals. Journal of Glaciology, Vol. 3, No. 24, p. 27 1-78.

Rigsby, G. P. 1958[b]. Fabrics of glacier and laboratory deformed ice. Union Géodésique et Géophysique Internationale. Association Internationale d'Hydrologie Scientifique. Symposium de Chamonix, 16-24 sept. 1958, p. 351-58.

Rigsby, G. P. I 960 . Crystal orientation in glacier and in experimentally deformed ice. Fournal of Glaciology, Vol. 3 ,
No. 27, p. 589-6o6.

Schytt, V. 1958. Glaciology. II. The inner structure of the ice shelf at Maudheim as shown by core drilling. Norwegian-British-Swedish Antarctic Expedition, 1949-52. Scientific Results (Oslo, Norsk Polarinstitutt), Vol. 4,
C, p. ${ }_{1} 3^{-52}$.

Seligman, G. 1949. The growth of the glacier crystal. Journal of Glaciology, Vol. 1, No. 5, p. 254-67.

Seligman, G. 1950. The growth of the glacier crystal: some further notes. Journal of Glaciology, Vol. I, No. 7, p. 379-81.

Shumskiy, P. A. 1958. The mechanism of ice straining and its recrystallization. Union Géodésique et Géophvsique Internationale. Association Internationale d'Hydrologie Scientifique. Symposium de Chamonix, 16-24 sept. 1958, p. 244-48.

Steinemann, S. 1954. Results of preliminary experiments on the plasticity of ice crystals. Fournal of Glaciology,
Vol, 2, No. 16, p. 404-13. 
Steinemann, S. [1956.] Flow and recrystallization of ice. Union Géodésique el Géophysique Internationale. Association Internationale d'Hydrologie Scientifique. Assemblée générale de Rome 1954, Tom. 4, p. 449-62.

Steinemann, S. 1958. Experimentelle Untersuchungen zur Plastizität von Eis. Beiträge zur Geologie der Schweiz. Geotechnische Serie. Hydrologie, Nr. Io.

Wade, F. A. 1945. The physical aspects of the Ross Shelf Ice. Proceedings of the American Philosophical Society, Vol. 89 , No. 1, p. $160-73$.

Zumberge, J. H., and others. 1960. Deformation of the Ross Ice Shelf near the Bay of Whales, Antarctica, by J. H. Zumberge, M. Giovinetto, R. Kehle and J. Reid. IGY Glaciological Report Series (New York, IGY World Data Center A, Glaciology), No. 3 . 